\title{
In vitro antimicrobial activity of ethanolic fractions of Cryptolepis sanguinolenta
}

\author{
Felix C Mills-Robertson', Samuel C K Tay² ${ }^{2}$, Goerge Duker-Eshun ${ }^{1}$, Williams Walana ${ }^{1}$ and Kingsley Badu ${ }^{3}$
}

\begin{abstract}
Background: Following claims that some plants have antimicrobial activities against infectious microbes, the in vitro antimicrobial activities of different solvent fractions of ethanolic extract of Cryptolepis sanguinolenta were evaluated against eight standard bacteria and clinical isolates.
\end{abstract}

Methods: The solvent partitioning protocol involving ethanol, petroleum ether, chloroform, ethyl acetate and water, was used to extract various fractions of dried pulverized Cryptolepis sanguinolenta roots. Qualitative phyto-constituents screening was performed on the ethanol extract, chloroform fraction and the water fraction. The Kirby Bauer disk diffusion method was employed to ascertain the antibiogram of the test organisms while the agar diffusion method was used to investigate the antimicrobial properties of the crude plant extracts. The microplate dilution method aided in finding the MICs while the MBCs were obtained by the method of Nester and friends. The SPSS 16.0 version was used to analyze the percentages of inhibitions and bactericidal activities.

Results: The phytochemical screening revealed the presence of alkaloids, reducing sugars, polyuronides, anthocyanosides and triterpenes. The ethanol extract inhibited 5 out of $8(62.5 \%)$ of the standard organisms and 6 out of $8(75 \%)$ clinical isolates. The petroleum ether fraction inhibited 4 out of $8(50 \%)$ of the standard microbes and 1 out of $8(12.5 \%)$ clinical isolates. It was also observed that the chloroform fraction inhibited the growth of all the organisms (100\%). Average inhibition zones of $14.0 \pm 1.0 \mathrm{~mm}$ to $24.67 \pm 0.58 \mathrm{~mm}$ was seen in the ethyl acetate fraction which halted the growth of $3(37.5 \%)$ of the standard organisms. Inhibition of 7 (87.5\%) of standard strains and $6(75 \%)$ of clinical isolates were observed in the water fraction. The chloroform fraction exhibited bactericidal activity against all the test organisms while the remaining fractions showed varying degrees of bacteriostatic activity.

Conclusion: The study confirmed that fractions of Cryptolepis sanguinolenta have antimicrobial activity. The chloroform fraction had the highest activity, followed by water, ethanol, petroleum ether and ethyl acetate respectively. Only the chloroform fraction exhibited bactericidal activity and further investigations are needed to ascertain its safety and prospects of drug development.

\section{Introduction}

Cryptolepis sanguinolenta (Lindl.) Schltr. (Periplocaceae) is a plant mostly found in the tropical rain forest regions of Africa with several species. C sanguinolenta is the most common in Ghana. This species is found on mountainous territories in Ghana, especially the Akwapim and Kwahu mountains [1,2]. Paulo and Houghton [3], described the plant as a slender thin stemmed climbing shrub with orange-coloured juice in the cut stem and

\footnotetext{
* Correspondence: scktaysammy9@yahoo.com

${ }^{2}$ Department of Clinical Microbiology, School of Medical Sciences, Kwame Nkrumah University of Science and Technology, Kumasi, Ghana Full list of author information is available at the end of the article
}

like most medicinal herbs or plants, the exact history on the usage of the plant is not well established, but it is confirmed that some indigenous inhabitants in the Akwapim and Kwahu mountainous areas in Ghana use the plant to manage various forms of fever, malaria and some infections caused by bacteria [4]. It has also been established that, the extract of $C$. sanguinolenta has antimuscarinic, vasodilating, noradrenergic, antithrombotic, anti-inflammatory, and hypoglycemic activities [5]. The part of the plant mostly used is the root and the extract is obtained in the aqueous form by boiling, or by alcohol extraction, popularly referred to as "bitters" in Ghana. Thus, $C$. sanguinolenta is a potential medicinal plant that

\section{Biomed Central}

(c) 2012 Mills-Robertson et al.; licensee BioMed Central Ltd. This is an Open Access article distributed under the terms of the Creative Commons Attribution License (http://creativecommons.org/licenses/by/2.0), which permits unrestricted use, distribution, and reproduction in any medium, provided the original work is properly cited. 
must be investigated to establish its antimicrobial activity. Previous in vitro studies have compared the effect of ethanol, cold and hot aqueous extracts of C. sanguinolenta as antimicrobial agents using Gram positive and Gram negative organisms as well as $C$. albicans. Eighty five percent of the test microbes were inhibited by the ethanol extract while the cold and hot aqueous extracts inhibited seventy five percent of the test microbes respectively [6]. The current study investigated the antimicrobial activity of various solvent fractions of ethanolic extract of C. sanguinolenta, with the aim of identifying the bioactive fractions of the extract as well as finding out the degree of activity against selected pathogenic bacteria.

\section{Methodology}

\section{Ethical issues}

The study protocol was approved by the Committee on Human Research Publication and Ethics of the School of Medical Sciences, Kwame Nkrumah University of Science and Technology (CHRPE/187/10). Informed consent was obtained from participants.

\section{Experimental materials}

Voucher specimens (Voucher \# CSRPM 1911), of the roots of $C$. sanguinolenta were harvested, dried and stored in the herbarium of the institute until needed.

\section{Test organisms used}

The test organisms used in this study were obtained from the Komfo Anokye Teaching Hospital (KATH), Kumasi, Ghana. These organisms were confirmed at the CSRPM using biochemical and Analytical Profile Index (API) kits. The isolates used consisted of one strain each of Staphylococcus aureus, Staphylococcus saprophyticus, Escherichia coli, Klebsiella pneumoniae, Proteus mirabilis, Pseudomonas aeruginosa, Salmonella typhi and Salmonella typhimurium. The following standard strains of bacteria were used; S. aureus ATCC 25923, S. saprophyticus ATCC 15305, E. coli ATCC 25922, K. pneumoniae ATCC 33495, Proteus mirabilis ATCC 49565, P. aeruginosa ATCC 27853, S. typhi ATCC 19430 and S. typhimurium ATCC 14028.

\section{Antibiotic susceptibility testing}

All the isolates were subjected to antimicrobial susceptibility test using Kirby-Bauer disc diffusion method as described by NCCLS [7]. Briefly peptone water subcultures which had attained the 0.5 McFarland turbidity standards were used to seed the surface of the MuellarHinton agar plates. Antibiotics disks [Amikacin $(30 \mu \mathrm{g}$ / disc), Ampicillin $(10 \mu \mathrm{g} /$ disc $)$, Penicillin $(10 \mu \mathrm{g} /$ disc $)$, Cloxacillin $(5 \mu \mathrm{g} /$ disc $)$, Erythromycin $(15 \mu \mathrm{g} /$ disc $)$, Tetracycline (30 $\mu \mathrm{g} /$ disc), Gentamicin (10 $\mu \mathrm{g} /$ disc), Cotrimoxazole (25 $\mu \mathrm{g} /$ disc), Chloramphenicol (30 $\mu \mathrm{g} /$ disc), and Cefixime
(30 $\mu \mathrm{g} /$ disc), Cefuroxime (30 $\mu \mathrm{g} / \mathrm{disc})$, and Cefotaxime (30 $\mu \mathrm{g} / \mathrm{disc})]$ were carefully placed on the surface of the plates and incubated at $37^{\circ} \mathrm{C}$ for $16-18$ hours.

\section{Ethanolic extract $C$. Sanguinolenta}

One kilogram (1 kg) of dried pulverized C. sanguinolenta roots was macerated in $8 \mathrm{~L}$ of $70 \%$ ethanol in water and stored at room temperature for 48 hours. The resultant extract was filtered, concentrated and subsequently freeze-dried. The freeze-dried sample was kept in the refrigerator at $4^{\circ} \mathrm{C}$ until needed. About 6 grams of the freeze-dried sample was reserved whilst the remaining was subjected to the solvent partitioning protocol as previously described $[8,9]$.

\section{Phytochemical screening of the extracts}

The phytochemical constituents of the ethanol extracts, chloroform fraction and the water fraction were determined. The phytochemical parameters assayed for, included saponins, reducing sugars, polyuronides, cyanogenic glycoside, alkaloid, triterpenes, phytosterols, flavonoids, anthocyanosides and phenolics [10].

\section{Antimicrobial activity of the fractions/compounds}

The agar diffusion method was used to investigate the antibacterial properties of both the crude ethanolic extracts and sequential solvent fractions of C. sanguinolenta, as described in the National Committee for Clinical Laboratory Standards [11] and the National Center for Infectious Disease, Center for Disease Control and Prevention [12].

\section{Determination of the minimum inhibitory concentration (MIC)}

The MIC values of the crude extract were determined using the microplate dilution method as described by Eloff [13]. Briefly, $100 \mu \mathrm{l}$ of $32 \mathrm{mg} / \mathrm{ml}$ of the ethanolic extract was added to $100 \mu \mathrm{l}$ of sterile bacteriological peptone in the first well in the 96-well microplate and mixed well with a micropipette, $100 \mu \mathrm{l}$ of this dilution was transferred to the bacteriological peptone in subsequent wells yielding two-fold serial dilution in the original extract. The process was repeated for the other plant extracts in other columns of the microplate. A reference solution of chloramphenicol was also serially diluted in another column of the microplate as a positive control. $100 \mu \mathrm{l}$ of actively growing test organisms (0.5 McFarland standards) was added to each of the wells except the negative control. Triplicate of each microplate was made and the procedure repeated for the other organisms. The microplates were incubated at $37^{\circ} \mathrm{C}$ for 24 hours. After the incubation, $40 \mu \mathrm{l}$ of $0.2 \mathrm{mg} / \mathrm{ml} \mathrm{INT}$ was added to each of the wells. The microplates were then examined after additional 60 minutes incubation. 
Bacterial growth is indicated by a red colour (conversion of the INT to formazan), and the lowest concentration at which the red colour is apparently invisible compared to the next dilution was taken as the MIC value.

\section{Determination of the minimum bactericidal concentration (MBC)}

The MBC values were deduced from those wells with the lowest concentrations at which no growth (colour development) was observed after culturing for 24 hours of incubation as described by Nester et al., [14].

\section{Results}

\section{Phytochemical screening}

Phytochemical screening performed on the ethanol extract as well as the water and chloroform fractions revealed the presence of reducing sugars, polyuronides, alkaloids and anthocyanosides. The water fraction in addition contains triterpenes (Table 1).

\section{Antibiotic susceptibility tests}

The antibiotic susceptibility test performed on all the 16 pathogenic bacteria revealed a high resistance pattern to all the first line antibiotics used in the study. It was observed that, all the microbes were resistant to AMP, CXC, TET and PEN, while the remaining antibiotics exhibited varying degrees of resistance and susceptibility (Figure 1).

\section{Susceptibility of the microbes to various fractions of $C$. Sanguinolenta}

As depicted in Table 2, 11 out of the 16 (68.75\%) microbes used were inhibited by the ethanol extract with average zones of inhibition ranging from $9.33 \pm 0.58$ to $35.67 \pm 0.58 \mathrm{~mm}$. Another 11 out of 16 isolates were not susceptible to the petroleum ether fraction; however, both the standard and wild strains of Proteus mirabilis were

Table 1 Phyto-constituents of the ethanol extract and the partitioned fractions

\begin{tabular}{llcl}
\hline \multicolumn{1}{c}{$\begin{array}{c}\text { Phytochemical } \\
\text { parameters }\end{array}$} & Ethanol & Water & Chloroform \\
\cline { 2 - 4 } Saponins & - & - & - \\
Reducing sugars & + & + & + \\
Polyuronides & + & + & + \\
Cyanogenic glycosides & - & - & - \\
Alkaloids & + & + & + \\
Triterpenes & - & + & - \\
Phytosterols & - & - & - \\
Flavonoides & - & - & - \\
Anthocyanosides & + & + & + \\
\hline
\end{tabular}

$+=$ present, $-=$ absent susceptible with $27.00 \pm 1.00 \mathrm{~mm}$ and $14.67 \pm 0.58 \mathrm{~mm}$ as the average zones of inhibition respectively. The chloroform fraction registered $100 \%$ inhibitory activity against all the sixteen isolates with inhibition zones averagely ranging between $9.33 \pm 0.58$ and $32.33 \pm 0.58 \mathrm{~mm}$. The ethyl acetate fraction inhibited the growth of 3 out of the $16(18.75 \%)$ isolates used with average zones of inhibition ranging from $14.00 \pm 1.00$ to $24.67 \pm 0.58 \mathrm{~mm}$. The water fraction of $C$. sanguinolenta inhibited 12 out of the 16 (75.00\%) microbes used with average zone diameters ranging from $8.67 \pm 0.58$ to $38.33 \pm 0.58 \mathrm{~mm}$ (Table 2). Chloramphenicol inhibited the growth of Proteus mirabilis (ATCC 49565), E. coli (ATCC 25922), S. aureus (ATCC 25923) and S. saprophyticus (ATCC 15305) representing $25.00 \%$ of the total number of microbes used.

\section{MICs and MBCs of the ethanol extract of C. Sanguinolenta} and its partitioned fractions

The MICs and MBCs of the partitioned fractions of $C$. sanguinolenta showed varying degrees of potency. These tests were performed only on the test organisms that showed inhibition during the antimicrobial screening. With the exception of the chloroform fraction which showed consistent bactericidal results in both MICs and MBCs to all the test organisms, the remaining fractions were bacteriostatic to the microbes. The ethanol extract had MIC values ranging from 8.0 to $32.0 \mathrm{mg} / \mathrm{ml}$ for the wild strains while that of the standard strains ranged from 4.0 to $32.0 \mathrm{mg} / \mathrm{ml}$. The chloroform extract had MIC values ranging from 1.0 to $2.0 \mathrm{mg} / \mathrm{ml}$ for the standard strains and 0.5 to $2.0 \mathrm{mg} / \mathrm{ml}$ for the wild strains with MBC values from 2.0 to $32.0 \mathrm{mg} / \mathrm{ml}$. The petroleum ether fraction exhibited MIC values ranging from 16.0 to $32.0 \mathrm{mg} / \mathrm{ml}$ among $P$. mirabilis, S. saprophyticus ATCC 15305, S. aureus ATCC25923, P. mirabilis ATCC 49565 and E. coli ATCC 25922, while MIC value of $32.0 \mathrm{mg} / \mathrm{ml}$ was observed among S. saprophyticus ATCC 15305, S. aureus ATCC25923 and P. mirabilis ATCC 49565 in the ethyl acetate fraction. The water fraction exhibited MIC values ranging from $8.0 \mathrm{mg} / \mathrm{ml}$ to $32.0 \mathrm{mg} / \mathrm{ml}$ in twelve of the microbes used (Table 3).

\section{Discussion}

The emergence of antibiotic resistance has prompted scientist to assiduously research into medicinal plants, not only to ascertain claims of efficacy and safety but also to discover alternative candidates for drug development. In the same regard the current study sought to elucidate the antimicrobial activity of ethanolic fractions of Cryptolepis sanguinolenta.

Several studies from the West African sub-region have reported the potency of $C$. sanguinolenta against clinical malaria $[4,15]$. The efficacy of its different alkaloids hydroxycryptolepine, cryptolepine $\mathrm{HCl}$ and the corresponding 


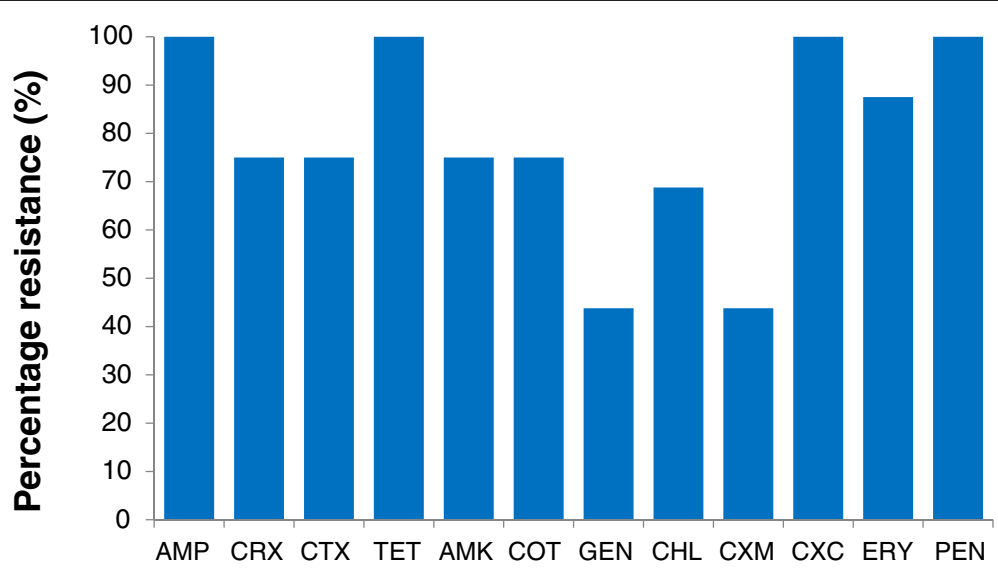

Antibiotics

Figure 1 Anti biotic resistance patterns of microorganisms used.

base cryptolepine as antifungal, antimalarial and antibacterial has also been reported [16,17].

High resistance observed in the clinical isolates is consistent with emerging antimicrobial resistance worldwide, especially in developing nations like Ghana [18,19]. All bacteria tested were completely resistant to the relatively affordable antibiotics available today; like ampicillin, cloxacillin, tetracycline and penicillin, while observed resistance to gentamicin was below fifty percent. High anti-bacterial resistance to ampicillin, chloramphenicol, streptomycin, sulphonamides and tetracycline in animals and humans has also been reported in Europe and America [20]. The simultaneous use of antimicrobial agents in both human and veterinary medicines have widened the spectrum of resistance to cover trimethoprim, fluoroquinolones and third-generation cephalosporin [21]. Even though there are natural ways microbes develop resistance [22], compliance with pharmaco-vigilance policies will help slow the rate of antibiotic resistance.

The phytochemical analyses revealed the presence of alkaloids, polyuronides and anthocyanosides in the ethanol extract, chloroform and water fractions. However, triterpenes were found only in the water fraction. There are reports on the antimicrobial activities of alkaloids

Table 2 Susceptibility of microbes to the extract and fractions of $C$. sanguinolenta

\begin{tabular}{|c|c|c|c|c|c|c|}
\hline Test Organisms & $\begin{array}{l}\text { Ethanol } \\
\text { extract }\end{array}$ & $\begin{array}{l}\text { Petroleum ether } \\
\text { fraction }\end{array}$ & $\begin{array}{l}\text { Chloroform } \\
\text { fraction }\end{array}$ & $\begin{array}{c}\text { Ethyl acetate } \\
\text { fraction }\end{array}$ & $\begin{array}{l}\text { Water } \\
\text { fraction }\end{array}$ & Chloram-phenicol \\
\hline Salmonella typhi ATCC 19430 & $18.00 \pm 0.00$ & $0.00 \pm 0.00$ & $19.67 \pm 0.58$ & $0.00 \pm 0.00$ & $16.67 \pm 1.15$ & $0.00 \pm 0.00$ \\
\hline Salmonella typhi & $0.00 \pm 0.00$ & $0.00 \pm 0.00$ & $11.33 \pm 0.58$ & $0.00 \pm 0.00$ & $0.00 \pm 0.00$ & $0.00 \pm 0.00$ \\
\hline Salmonella typhimurium ATCC 14028 & $0.00 \pm 0.00$ & $0.00 \pm 0.00$ & $11.33 \pm 0.58$ & $0.00 \pm 0.00$ & $0.00 \pm 0.00$ & $0.00 \pm 0.00$ \\
\hline Salmonella typhimurium & $0.00 \pm 0.00$ & $0.00 \pm 0.00$ & $9.33 \pm 0.58$ & $0.00 \pm 0.00$ & $0.00 \pm 0.00$ & $0.00 \pm 0.00$ \\
\hline Proteus mirabilis ATCC 49565 & $9.33 \pm 0.58$ & $27.00 \pm 1.00$ & $20.67 \pm 0.58$ & $14.00 \pm 1.00$ & $10.33 \pm 0.58$ & $14.67 \pm 0.58$ \\
\hline Proteus mirabilis & $20.67 \pm 0.58$ & $14.67 \pm 0.58$ & $19.33 \pm 0.58$ & $0.00 \pm 0.00$ & $18.67 \pm 0.58$ & $0.00 \pm 0.00$ \\
\hline Pseudomonas aeruginosa ATCC 27853 & $0.00 \pm 0.00$ & $0.00 \pm 0.00$ & $11.00 \pm 1.00$ & $0.00 \pm 0.00$ & $9.67 \pm 0.58$ & $0.00 \pm 0.00$ \\
\hline Pseudomonas aeruginosa & $20.00 \pm$ & $0.00 \pm 0.00$ & $15.67 \pm 0.58$ & $0.00 \pm 0.00$ & $24.33 \pm 1.15$ & $0.00 \pm 0.00$ \\
\hline Klebsiella pneumoniae ATCC 33495 & $0.00 \pm 0.00$ & $0.00 \pm 0.00$ & $10.67 \pm 0.58$ & $0.00 \pm 0.00$ & $0.00 \pm 0.00$ & $0.00 \pm 0.00$ \\
\hline Klebsiella pneumonia & $22.33 \pm 0.58$ & $0.00 \pm 0.00$ & $15.67 \pm 0.58$ & $0.00 \pm 0.00$ & $23.67 \pm 0.58$ & $0.00 \pm 0.00$ \\
\hline Escherichia coli ATCC 25922 & $19.67 \pm 0.58$ & 19.670 .58 & $14.67 \pm 0.58$ & $0.00 \pm 0.00$ & $21.33 \pm 1.15$ & $14.33 \pm 0.58$ \\
\hline Escherichia coli & $9.67 \pm 0.58$ & $0.00 \pm 0.00$ & $11.33 \pm 0.58$ & $0.00 \pm 0.00$ & $8.67 \pm 0.58$ & $0.00 \pm 0.00$ \\
\hline Staphylococcus aureus ATCC 25923 & $35.67 \pm 0.58$ & 32.670 .58 & $32.33 \pm 0.58$ & $24.67 \pm 0.58$ & $38.33 \pm 0.58$ & $26.00 \pm 1.00$ \\
\hline Staphylococcus aureus & $18.67 \pm 0.58$ & $0.00 \pm 0.00$ & $14.33 \pm 0.58$ & $0.00 \pm 0.00$ & $17.00 \pm 2.00$ & $0.00 \pm 0.00$ \\
\hline Staphylococcus saprophyticus ATCC 15305 & $20.33 \pm 0.58$ & $24.33 \pm 1.15$ & $19.67 \pm 0.58$ & $17.33 \pm 0.58$ & $21.00 \pm 1.00$ & $19.33 \pm 0.58$ \\
\hline Staphylococcus saprophyticus & $10.00 \pm 0.00$ & $0.00 \pm 0.00$ & $10.67 \pm 0.58$ & $0.00 \pm 0.00$ & $9.33 \pm 0.58$ & $0.00 \pm 0.00$ \\
\hline
\end{tabular}


Table 3 The MIC and MBC of the extract and fractions of $C$. sanguinolenta

\begin{tabular}{|c|c|c|c|c|c|c|c|c|c|c|}
\hline \multirow[t]{2}{*}{ Test organisms } & \multicolumn{2}{|c|}{ Ethanolic extract } & \multicolumn{2}{|c|}{$\begin{array}{c}\text { Petroleum ether } \\
\text { extract }\end{array}$} & \multicolumn{2}{|c|}{ Chloroform extract } & \multicolumn{2}{|c|}{ Ethyl acetate extract } & \multicolumn{2}{|c|}{ Water extract } \\
\hline & MIC & MBC & MIC & MBC & MIC & MBC & MIC & MBC & MIC & MBC \\
\hline Salmonella typhi & 32.0 & BST & $x$ & $x$ & 1.0 & 4.0 & $x$ & $x$ & 8.0 & BST \\
\hline \multicolumn{11}{|l|}{ ATCC 19430} \\
\hline Salmonella typhimurium ATCC 14028 & $x$ & $x$ & $x$ & $x$ & 2.0 & 4.0 & $x$ & $x$ & $x$ & $x$ \\
\hline Proteus mirabilis ATCC 49565 & 32.0 & BST & 32.0 & BST & 2.0 & 2.0 & 32.0 & BST & 16.0 & BST \\
\hline Pseudomonas aeruginosa ATCC 27853 & $x$ & $x$ & $x$ & $x$ & 2.0 & 4.0 & $x$ & $x$ & 16.0 & BST \\
\hline Klebsiella pneumoniae ATCC 33495 & $x$ & $x$ & $x$ & $x$ & 4.0 & 8.0 & $x$ & $x$ & $x$ & $x$ \\
\hline Escherichia coli & 16.0 & BST & 16.0 & BST & 4.0 & 16.0 & $x$ & $x$ & 8.0 & BST \\
\hline \multicolumn{11}{|l|}{ ATCC 25922} \\
\hline Staphylococcus aureus & 4.0 & BST & 32.0 & BST & 2.0 & 4.0 & 32.0 & BST & 16.0 & BST \\
\hline \multicolumn{11}{|l|}{ ATCC 25923} \\
\hline Staphylococcus saprophyticus ATCC 15305 & 4.0 & BST & 16.0 & $x$ & 2.0 & 4.0 & 32.0 & BST & 32.0 & BST \\
\hline \multicolumn{11}{|l|}{ Clinical Isolates } \\
\hline Salmonella typhi & $x$ & $x$ & $x$ & $x$ & 1.0 & 8.0 & $x$ & $x$ & $x$ & $x$ \\
\hline Salmonella typhimurium & $x$ & $x$ & $x$ & $x$ & 2.0 & 16.0 & $x$ & $x$ & $x$ & $x$ \\
\hline Proteus mirabilis & 8.0 & BST & 32.0 & BST & 1.0 & 8.0 & $x$ & $x$ & 32.0 & BST \\
\hline Pseudomonas aeruginosa & 32.0 & BST & $x$ & $x$ & 1.0 & 8.0 & $x$ & $x$ & 32.0 & BST \\
\hline Klebsiella pneumoniae & 32.0 & BST & $x$ & $x$ & 2.0 & 32.0 & $x$ & $x$ & 32.0 & BST \\
\hline Escherichia coli & 32.0 & BST & $x$ & $x$ & 1.0 & 32.0 & $x$ & $x$ & 32.0 & BST \\
\hline Staphylococcus aureus & 32.0 & BST & $x$ & $x$ & 0.5 & 4.0 & $x$ & $x$ & 16.0 & BST \\
\hline Staphylococcus saprophyticus & 32.0 & BST & $x$ & $x$ & 1.0 & 4.0 & $x$ & $x$ & 16.0 & BST \\
\hline
\end{tabular}

$\mathrm{X}=$ no test done, $\mathrm{BST}=$ Bacteriostatic.

against wide spectra of microbes- according to Cimanga et al., [18], ethanol-water extract isolation of the alkaloids quindoline, hydroxycryptolepine, cryptolepine- $\mathrm{HCl}$, and the corresponding base cryptolepine was found to inhibit Gram-positive bacteria and some selected Gramnegative bacteria [18]. Terpenoids are known to have antimicrobial properties [23]. For instance, triterpenes, terpenoids or isoprenoids, are reported to show high antifungal or antimicrobial properties with possible effect on the non-mevalonate pathway. This pathway is essential in fungi, protozoans, gram-negative bacteria and other micro-organisms for the synthesis of cell membrane components, prenylation of proteins and as a secondary source of carbon [24]. Reducing sugars have been reported to have antibacterial property $[25,26]$. The petroleum ether acting as a defatting agent removed oils from the extract. This may be a contributing factor to the microbial susceptibility observed since most oils from plants have antimicrobial activity [27]. The activity of these phytochemical-constituents may be responsible for the antimicrobial activities observed in the study.

The ethanol extract inhibited both Gram positive and Gram negative bacteria with greater inhibition zones observed among the Gram-positive microbes, probably due to difference in cell wall structure and component. This result is consistent with the work of MillsRobertson et al., [6]. The inhibition of S. saprophyticus, E. coli and P. mirabilis confirm the use of the plant in the treatment of UTI [28]. Aqueous and 80\% Ethanolwater extract from the root-bark of Cryptolepis sanguinolenta are known to have potent antibacterial, anticomplementary, and moderate antiviral activities, but not antifungal [18]. The petroleum ether fraction of the ethanol extract of C. sanguinolenta inhibited the growth of only the standard Gram-positive bacteria; however, both the standard and wild strains of Proteus mirabilis were susceptible. C. sanguinolenta has been shown to contain alkaloids which function to cause cell lysis and morphological changes in S. aureus [29]. The inhibition of only the Gram-positive organisms as well as Proteus mirabilis by the petroleum ether fraction may suggest the presence of such compounds; hence the fraction may be used as narrow spectrum antimicrobial.

The chloroform fraction registered hundred percent inhibitory activities against all the sixteen isolates. Paulo et al., [17] investigated the antimicrobial activity of ethanol extract and five alkaloids of C. sanguinolenta and observed that $P$. aeruginosa was resistant to all the alkaloids and the 
extract. However, this present study observed that the chloroform fraction of $C$. sanguinolenta has inhibitory activity against $P$. aeruginosa; hence, the fraction may be used in the treatment of infections involving these MDR organisms. The chloroform extracts of Thaumatococcus danielli leaves have no significant antimicrobial activity against Salmonella typhimurium, Shigella sp, Escherichia coli and Staphylococcus aureus [30]. Moreover chloroform extracts of Centrosema pubescens inhibited the growth of same organisms [31], a justification that the inhibition was not caused by chloroform but rather its constituents. It is thought that chloroform has the potential of extracting some potent compounds which are present in minute proportion in the ethanolic extract. In addition, synergism may be a plausible explanation for this observation [32-34]. These phenomena requires further investigated.

The ethyl acetate fraction inhibited the growth of three out of the sixteen (18.75\%). All the other test microbes $(n=13)$ were not susceptible to the extract. The few organisms inhibited by the fraction could be justified by the dose-dependent activity observed by Cimanga et al., [18]. Probably the active compounds contained in the fraction were not sufficient to inhibit most of the organisms. The water fraction of C. sanguinolenta inhibited twelve out of the sixteen $(75.00 \%)$ microbes used. The growths of all the Gram-positive microbes were inhibited. Non susceptibility was observed among S. typhi, S. typhimurium, S. typhimurium (ATCC 14028) and K. pneumoniae (ATCC 33495). The remaining eight Gram-negative organisms were inhibited by the extract. The aqueous fraction has been reported to have a broad spectrum antimicrobial activity [6].

Gram-positive test organisms were generally susceptible to the various fractions used. This may be due to the about $90 \%$ peptidoglycan component of the cell wall of Grampositive bacteria, which is not a regulatory in comparison to the cell membrane of the gram negative bacteria, and therefore, incapable of performing the function of selective permeability, and thus allow substances to sieve through it. The Gram-negative organisms showed varying resistance to all fractions and extract except the chloroform fraction. The Gram-negative bacteria cell wall consist of a periplasmic space that contains many hydrolytic enzymes, including $\beta$-lactamase, which destroy potentially dangerous foreign substances present in this space.

All the extract and fractions showed MIC values ranging from $0.5 \mathrm{mg} / \mathrm{ml}$ to $32 \mathrm{mg} / \mathrm{ml}$ but not all were bactericidal. Considering the fact that the chloroform fraction used is a crude extract, the MIC value recorded $(0.5 \mathrm{mg} / \mathrm{ml})$ against $S$. aureus and a maximum of $4 \mathrm{mg} /$ $\mathrm{ml}$ in the other test organisms shows how potent it could be used as an antimicrobial agent. MICs observed in this study are high compared to some studies like Akiyemi et al. [35]. They reported the effectiveness of crude extracts of three medicinal plants from Nigeria against MRSA, and observed MICs ranging from 18.2 to $71.0 \mathrm{ug} / \mathrm{ml}$. Another study [36] determined the antimicrobial activity of three selected plants against Extended Spectrum Beta Lactamase (ESBL) - producing Escherichia coli and Klebsiella pneumoniae and found majority of the microorganisms inhibited by 40 and $80 \mu \mathrm{g} / \mu \mathrm{l}$ of the crude extracts. However the current MICs observed is consistently justified by similar studies. Navarro et al. [37] investigating 12 methanolic plant extracts normally used in traditional medicine in Mexico to cure infectious diseases, examined the potential antimicrobial activity against Staphylococcus aureus, Escherichia coli, Pseudomonas aeruginosa and Candida albicans. They reported significant antimicrobial effects, as MICs, ranging between 0.6 and $40 \mathrm{mg} / \mathrm{ml}$ of crude extract against the microbes. Another study also reported that Gramnegative bacteria are hardly susceptible to the plant extracts in doses less than $2 \times 10^{5} \mu \mathrm{g} / \mathrm{mL}$ [38].

\section{Conclusion}

In conclusion, the study confirmed that fractions of Cryptolepis sanguinolenta have significant antibacterial activity. Different fractions have varying antibacterial activity against different organisms. The chloroform fraction had the highest activity, followed by water, ethanol, petroleum ether and ethyl acetate respectively. It is recommended that more research be conducted into the individual compounds in the extracts; there is promise in such to find very low MICs.

\section{Competing interest}

The authors declared that they have no competing interests.

\section{Authors' contributions}

FCMR, SCKT, GDE conceived the study and designed the study protocols and supervised laboratory tests, WW collected laboratory specimen, carried out the test and wrote the first draft, KB participated in data analysis, and manuscript development. All authors read and approved the manuscript.

\section{Acknowledgements}

The study was financially supported by the Centre for Scientific Research into Plant Medicine, (CSRPM) Mampong-Akwapim, Ghana. We are grateful to the staff of the Department of Microbiology at CSRPM, especially Sylvester Kaminta and his colleagues for their support. The work is part of MSc thesis of WW.

\section{Author details}

${ }^{1}$ Department of Microbiology, Centre for Scientific Research into Plant Medicine, Mampong-Akwapim, Ghana. ${ }^{2}$ Department of Clinical Microbiology, School of Medical Sciences, Kwame Nkrumah University of Science and Technology, Kumasi, Ghana. ${ }^{3}$ Kenya Medical Research Institute Center for Global Health, Research Climate and Human Health Research Unit, Kisumu, Kenya.

Received: 14 February 2012 Accepted: 5 June 2012

Published: 18 June 2012

\section{References}

1. IWU MM: The Handbook of African Medicinal Plants. 200 N. W. Corporate, USA: CRC Press; 1993:221-222. 
2. Addy M: Cryptolepis: An African traditional medicine that provides hope for malaria victims. HerbalGram 2003, 60:54-59.

3. Paulo A, Houghton PJ: Chemotaxonomic analysis of the genus Cryptolepis. Biochem Syst Ecol 2003, 31:155-166.

4. Boye LG, Oku-Ampofo O: Medicinal plants in Ghana. Economic and Medicinal Plant research. Plants Traditional Med 1990, 4:32-33.

5. Bierer DE, Fort DM, Mendez CD, Luo J, Imbach PA, Dubenko LG, Jolad SD, Gerber RE, Litvak J, Lu Q, Zhang P, Reed MJ, Waldeck N, Bruening RC, Noames BK, Hector RF, Carlson TJ, King SR: Ethnobotanical-directed discovery of the antihyperglycaemic properties of cryptolepine: Its isolation from Cryptolepis sanguinolenta, synthesis and in vitro and in vivo activities. J Med Chem 1998, 41:894-901.

6. Mills-Robertson FC, Aboagye FA, Duker-Eshun G, Kaminta S, Agbeve S: In vitro antimicrobial activity of Cryptolepis sanguinolenta (periplocaceae). Afr J Pharm Pharmacol 2009, 3:(9)476-480.

7. National Committee for Clinical Laboratory Standards: Performance standards for antimicrobial disk susceptibility tests. Approved standard M2 A6. Wayne, PA, USA 1998

8. Grode SH, James TR, Cardellina JH, Onan KD: Methyl briareolate, the first briarein diterpene containg a C-19 methyl ester. J Org Chem 1983, 48:5203-5207.

9. Duker-Eshun G, Jaroszewski JW, Asomaning WA, Oppong-Boachie F: Antiplasmodial constituents of Cajanus cojan. Centre Sci Res Plant Med 2004, 18:128-130.

10. Sofowora A: Medicinal plants and traditional medicine. Ibadan, Nigeria: Spectrum books Limited; 1993:224-227.

11. National Committee for Clinical Laboratory Standards (NCCLS): Methods for dilution antimicrobial susceptibility tests for bacteria that grow aerobically. Wayne, PA, USA: Approved Standard M7-A4, NCCLS; 2000.

12. National Center for Infectious Disease, Center for Disease Control and prevention, WHO: Laboratory Methods for the Diagnosis of Epidemic Dysentery and Cholera, Center for Disease Control and prevention. Atlanta, Georgia, USA 1999:71-72

13. Eloff $\mathrm{JN}$ : A sensitivity and quick microplate method to determine the minimal inhibition concentration of plant extracts for bacterial. Planto Med 1998, 64(8):711-713.

14. Nester EW, Anderson DG, Roberts CE Jr, Pearsall NN, Nester T, Hurley D: Microbiology, A Human Perspective, Volume 518, 614. Fourth Editionth edition. New York, USA: MacGraw-Hill; 2004:640-641.

15. Bugyei KA, Boye GL, Addy ME: Clinical Efficacy of a Tea-Bag Formulation of Cryptolepis Sanguinolenta Root in the Treatment of Acute Uncomplicated Falciparum Malaria. Ghana Med J 2010, 44(1):3-9.

16. Paulo A, Pimentel M, Viegas S, Pires I, Duarte A, Cabrita J, Gomes ET: Cryptolepis sanguinolenta activity against diarrhoeal bacteria. J Ethnopharmacol 1994, 44(2):73-77.

17. Cimanga K, De Bruyne T, Lasure A, Van Poel B, Pieters L, Claeys M, Berghe DV, Kambu K, Tona L, Vlietinck AJ: In vitro biological activities of alkaloids from Cryptolepis sanguinolenta. Planta Med 1996, 62(3):288

18. Okeke IN, Lamikaure A: Edelman: Socioeconomic and Behavioural Factors Leading to Acquired Bacterial Resistance to Antibiotics in Developing Countries. Emerg Infect Dis 1999, 5(1):1-9.

19. Ako-Nai AK, Adeyemi FM, Aboderin OA, Kassim OO: Antibiotic resistance profile of staphylococci from clinical sources recovered from infants. Afr J Biotechnol 2005, 4(8):816-822.

20. Poppe CSN, Khakhria R, Johnson W, Spika J, Prescott J: Salmonella Typhimurium DT104: A virulent and drug-resistant pathogen. Can Vet J 1998, 39:559-565.

21. Rabsch W, Tschäpe H, Bäumler AJ: Non-typhoidal salmonellosis: emerging problems. Microb Infect 2001, 3:227-237.

22. Jawetz E, Levinson W: Microbiology and Immunology. 4th edition. USA: Appleton and Lang; 1996:57-109.

23. Scortichini M, Pia RM: Preliminary in vitro evaluation of the antimicrobial activity of triterpenes and terpenoids towards Erwinia amylovora (Burrill). J Bacterio/ 1991, 71:109-112.

24. Nayak BS, Ramdath DD, Marshall JR, Isitor GN, Eversley M, Xue S, Shi J: Wound healing activity of the skin of the common grape (Vitis vinifera) Variant, Cabernet Sauvignon. Phytother Res 2010, 24(8):1151-1157.

25. Mabeku LBK, Penlap BV, Ngadjui BT, Fomum ZT, Etoa FX: Evaluation of Antimicrobial Activity of the Stem Bark of Cylicodiscus Gabunensis (Mimosaceae). Afr J Tradit Compl Alternative Med 2007, 4(1):87-93.
26. Dhale1 DA, Markandeya SK: Antimicrobial and Phytochemical Screening of Plumbago zeylanica Linn. (Plumbaginaceae) Leaf. J Exp Sci 2011, 2 (3):04-06.

27. Akgul C, Saglikoglu G: Antibacterial activity of crude methonolic extract and its fractions of aerial parts of Anthemis tinctoria. Indian J Biochem Biophys 2005, 42:395-397.

28. Slack R, Greenwood D, Peutherer J, Barer M: Medical Microbiology. 17th edition. New York: Elsevier; 2007:173-298.

29. Sawer IK, Berry Ml, Ford JL: The killing effect of cryptolepine on Staphylococcus aureus. Lett Appl Microbiol 2005, 40(1):24-29.

30. Ojekale AB, Makinde SCO, Osileye O: Phytochemistry and anti-microbial evaluation of Thaumatococcus danielli, Benn. (Benth.) leaves. Nigerian Food Journal 2007, 25(2):176-183.

31. Ekpo M, Mbagwu H, Jackson C, Eno M: Antimicrobial and wound healing activities of Centrosema pubescens (Leguminosae). J Pharm Clin Sci 2011, $1: 1-6$

32. Spinella M: The Importance of Pharmacological Synergy in Psychoactive Herbal Medicines. Alternative Med Rev 2002, 7(2):130-137.

33. Toews ML, Bylund DB: Pharmacologic principles for combination therapy. Proc Am Thorac Soc 2005, 2(4):282-289.

34. WHO: General guidelines for methodologies on research and evaluation of traditional medicine. Geneva: World Health Organization; 2000.

35. Akinyemi KO, Oladapo O, Okwara CE, Ibe CC, Fasure KA: Screening of crude extracts of six medicinal plants used in South-West Nigerian unorthodox medicine for anti-methicillin resistant Staphylococcus aureus activity. BMC Compl Alternative Med 2005, 5:6. doi:10.1186/1472-6882-5-6.

36. Abdel-Massih R, Abdou E, Baydoun E, Daoud Z: Antibacterial Activity of the Extracts Obtained fromRosmarinus officinalis, Origanum majorana, andTrigonella foenum-graecum on Highly Drug-Resistant Gram Negative Bacilli. J Bot Vol 2010, 464087:8. doi:10.1155/2010/464087.

37. Navarro V, Villarreal LM, Rojas G, Lozoya X: Antimicrobial evaluation of some plants used in Mexican traditional medicine for the treatment of infectious. J Ethnopharmacol 1996, 53:143-147.

38. Suffredini IA, Paciencia ML, Nepomuceno DC, Younes RN, Varella AD: Antibacterial and Cytotoxic Activity of Brazilian Plant Extracts Clusiaceae. Mem Inst Oswaldo Cruz 2006, 101:287-290.

doi:10.1186/1476-0711-11-16

Cite this article as: Mills-Robertson et al.: In vitro antimicrobial activity of ethanolic fractions of Cryptolepis sanguinolenta. Annals of Clinical Microbiology and Antimicrobials 2012 11:16.

\section{Submit your next manuscript to BioMed Central and take full advantage of:}

- Convenient online submission

- Thorough peer review

- No space constraints or color figure charges

- Immediate publication on acceptance

- Inclusion in PubMed, CAS, Scopus and Google Scholar

- Research which is freely available for redistribution 